To cite this article: Dickson Dillimono, H. \& Dickinson, J.E. (2015) Travel, tourism, climate change, and behavioral change: travelers' perspectives from a developing country, Nigeria. Journal of Sustainable Tourism, 23(3), 437-454.

\title{
Travel, tourism, climate change and behavioral change: travelers' perspectives from a developing country, Nigeria
}

\begin{abstract}
While studies have examined people's understanding of climate change and its relationship to tourism, these focus largely on developed country populations. Much future tourism growth will come from developing countries following economic development, often countries where climate change will be strongly felt. Do tourists from developing countries have the same knowledge gaps about travel, tourism and climate change as in the developed world? Will behavioral change policies be successful in encouraging more environmentally friendly approaches to climate change and tourism in developing countries? This paper presents findings from 20 in-depth interviews with active Nigerian tourists, analyzing their understanding of climate change, the links known, or not, between their travel and climate change, and their willingness to change their tourism patterns. Understanding of climate change was limited and there was conceptual confusion. Participants did not view their own travel as a cause of climate change and many were embedded in air travel practice.

Participants were unwilling to change their tourism patterns to reduce their contribution to climate change. Significant structural barriers limit low carbon tourism travel in Nigeria (and other developing countries), including reliability, availability, safety and speed. Behavioral change will be difficult to achieve.
\end{abstract}

Keywords: climate change; Nigerian tourists; social practices, behavioral change, developing countries

\section{Introduction}

Many developing countries, including Nigeria, are particularly vulnerable to climate change partly because of existing difficult climatic conditions and partly because of poor adaptive capacity due to relative poverty (Parry, Canziani, Palutikof, van der Linden \& Hanson, 2007). Developing countries often depend more on climate-sensitive economic sectors and often have poorly equipped infrastructure (Nath \& Behera, 2011). They are known as vulnerable countries (Tol, 2004) and will be more exposed to problems related to water supply, health, food security and poor economic conditions as climate changes take place. With its present climate, Africa is already facing challenges such as food crises and water scarcity which is intensified by the fast rate of population growth (McMichael, Barnett \& McMichael, 2012). Nigeria, the most populous country in Africa, already suffers from deteriorating food security and is projected to suffer from a reduction in the length of the growing period (Parry et al., 2007), declining crop yields, sea level rise and an increasing spread of disease (Ikeme, 2003).

It is assumed that much of the future global growth in tourism will be derived from developing countries, with Africa likely to show strong outbound tourism growth, much of it by air, albeit from a low base (World Tourism Organization, 2011). For instance, while Nigeria has seen a decline in non-resident arrivals since 2010 (World Tourism Organization 2012a) due to political upheaval, it has seen consistent growth in outbound tourism (World Tourism Organization 2012b). However, tourism generates greenhouse gas (GHG) emissions and it is acknowledged that tourism and travel play a growing role in climate change (Miller, Rathouse, Scarles, Holmes \& Tribe, 2010; Scott, Hall \& Gössling, 2012) and tourism growth 
is predicted to outpace technological advancements that might curtail the GHG emissions that cause climate change (Becken, 2007). Consequently, growth in tourism, though being evidence of a country's development and, in some instances, an economic development opportunity, may paradoxically bring problems, as a result of increasing climate change.

A tourism development pathway with lower GHG emissions is dependent, to a large extent, on an understanding of climate change and its causes as a precursor to implementing appropriate strategies. While a number of studies have analyzed people's attitudes and understanding of climate change in relation to tourism and travel (Anable, Lane \& Kelay, 2006, Becken, 2007; Cohen, Higham \& Cavaliere, 2011; Hares, Dickinson \& Wilkes, 2010; Higham \& Cohen, 2011; Kempton, 1997; Pickering, Castley \& Burtt, 2010; Randles \& Mander, 2009), these focus on developed countries, for example, the USA, UK, Norway and New Zealand. Dickinson, Robbins, Filimonau, Hares \& Mika (2013) focus on a Polish sample, considered an emerging economy, but there is a gap in knowledge regarding developing countries, especially those vulnerable to climate change. This question was considered at the 2012 Freiburg Workshop on psychological and behavioral approaches to understanding and governing sustainable mobility, and a call made for "lines of enquiry...to be extended to emergent world regions" (including Nigeria), "where rapidly expanding middle classes are fueling increases in aero-consumption" (Higham, Cohen, Peeters \& Gössling, 2013, 962).

In the Nigerian context, a recent study analyzed people's understanding of climate change with respect to the mass media (Akpan, Anorue\& Ukonu, 2012). No work has explored climate change in respect to the tourism or travel context, an aspect of the Nigerian economy open to future growth with potential for a sustainable development strategy.

This study therefore analyses the Nigerian public's understanding of climate change with respect to tourism and explores their willingness to change behavior to reduce the impact of their tourism on climate change. The focus is purposefully on more affluent Nigerians who are currently able to engage in international tourism. Poverty prevents many Nigerians engaging in any form of tourism at the present time and low income groups are therefore not the focus of this study. Affluent Nigerians are indicative of developing country populations from which future tourism growth will be derived. An understanding of this group is vital to design intervention strategies that might bring about more positive tourism practices in Nigeria in order to develop low carbon tourism.

\section{Climate change and tourism}

Over the last decade, there has been an increased interest in the interrelationship between tourism and climate change. Certain destinations and tourism businesses are susceptible to climate change (Higham \& Cohen, 2011; Schott, 2010) and significant tourism environmental resources, such as fresh water, snow depth and biodiversity are affected by the climate (Higham \& Cohen, 2011). Due to higher risk of exposure to climate change and poor adaptive capacity, developing countries that depend on tourism as a means of economic growth are likely to be more affected by the impact of climate change (Schott, 2010).

Tourism in developing countries is also indirectly affected by climate change through changes that impact on the economic and political state of nations. For instance political instability resulting from climate related disasters can lead to violence and negative associations with places that affect people's willingness to visit (Simpson, Gössling, Scott, 
Hall \& Gladin, 2008). Vulnerable countries are likely to experience more economic and political instability due to climate change suggesting that tourism development may be a poor development strategy in the long term (Peeters, 2009). At the same time, national and international carbon emissions mitigation policies are increasingly being established, resulting in increased transport prices, which are anticipated to impact on tourist flows (Marshall, Marshall, Abdulla, Rouphael \& Ali, 2011). Marshall et al. (2011) suggest this may result in less long-haul travel with implications for many developing countries far from tourism source markets. Officials in Africa have already expressed concern about the effect this would have on the tourism economy (Simpson et al., 2008).

Emissions from the tourism sector are expected to increase in the future due to increasing growth in the number of people involved in both domestic and international tourism leading to a global increase in trips and accommodation capacity, and growing energy intensity of most trips (Becken, 2007; Scott, Peeters \& Gössling, 2010). Air travel is recognized as a growing contributor to GHG emissions and, compared to other modes of transportation, it is considered to have the greatest impact on climate change (Becken, 2007; Cohen \& Higham, 2011).

Work in the 1990's (Stoll-Kleemann, O'Riordan \& Jaeger, 2001, p. 110) argued that the public had relatively little knowledge of the "causes and the underlying science of climate change" suggesting that they are not able to connect climate change to energy systems and to transport in a clear manner. While some later research seems to reinforce this finding (see for example, Miller et al., 2010), there is some evidence that the public's knowledge of climate change is improving in developed countries (see, for example, Cohen et al., 2011). Anable et al. (2006) suggest it may be unrealistic to expect the public to view climate change in the same way as scientists or policy analysts and Lorenzoni and Pidgeon (2006, p. 74), when looking at the European and USA context, argued that:

"Climate change is a very complex, pervasive and uncertain phenomenon, generally difficult for people to conceptualise and to relate to their daily activities, arguably because it cannot be easily translated into the language of popular culture"

Understanding of abstract concepts like climate change often emerges from societal discourse (Dickinson et al., 2013) and Kempton (1997) suggests climate change has been understood by reference to other environmental problems such as ozone depletion and pollution.

People's awareness of climate change can have a direct impact on tourist patterns due to a shift in climatic appeal and image of the destination (Hall \& Higham, 2005). This may be particularly prevalent in Africa where destinations have a reputation for hot climates. Given that tourism transport contributes around $75 \%$ of the share of tourism GHG emissions (Scott et al., 2010) tourists may shift travel patterns in recognition of the impact of their actions on climate change (Lorenzoni \& Pidgeon, 2006), however, there is currently little evidence of this taking place. Most studies indicate a continued desire to take international holidays to long-haul destinations and Cohen and Higham (2011) suggest this has become an expectation. Cohen and Higham found only a small number of participants were beginning to re-evaluate air travel in light of its contribution to climate change. This is reinforced by several earlier studies (see, for example, Hares et al., 2010; McKercher, Prideaux, Cheung \& Law, 2010). 
Studies within the sociology of consumption, particularly those using social practices theory, have analyzed the understanding of climate change and how practice is structured by society (Dickinson, Robbins \& Lumsdon, 2010; Miller et al., 2010; Randles \& Mander, 2009). Social practice theory moves away from the individual unit of analysis, that is the focus of attitude and behavior studies, to focus on activity patterns that are shared by groups of people and become routinized in everyday life (Spaargaren \& van Vliet, 2000). These activity patterns, known as "social practices", become both embedded in and continually reproduced by society's physical and social structures (Reckwitz, 2002). The theory acknowledges the role of both the individual actor/agent and the structures present in a given society. Of relevance to tourism, social practice studies have offered some explanation for why flying is the mode of choice even in cases where individuals express high levels of concern about its impact on climate change. It appears the physical and social structures prevalent in a given society are powerful forces that mediate individual agency (Dickinson et al., 2013).

\section{The Nigerian context}

Nigeria, in West Africa, has a population of over 140 million. While tourism has been considered a potential economic development option for the country, should political stability improve, it is currently under developed. It has a wide range of natural tourism attractions, including coastal beaches and rich ecological attractions, including mountains, waterfalls, lakes, hills and caves (Mintel, 2007), together with a rich heritage of traditional arts and crafts (Nigerian Tourism Development Corporation, 2012). Despite these attributes, the tourism sector in Nigeria is still at the development stage, most of the attractions are untouched and are enjoyed by few foreigners, mostly the rich or adventure tourists (Mintel, 2007). The Nigerian government showed an interest in tourism development with the establishment of the Nigerian Tourism Board in 1976, known as the Nigerian Tourism Development Corporation since 1992. Tourism has been recognized as one the "six priority areas" in need of development (Esu, 2012) however, Iyiola and Akintunde (2011, p.28) argue that the sector has "suffered a great deal during the past military and civilian rule" and Nigeria, unlike other countries, has invested little in tourism.

There is inadequate statistical data with regards to tourism in Nigeria. The available data from 2005 shows that the majority of arrivals (50\%) relate to business travel (Mintel, 2007). Due to the size of the country, air travel is the quickest and preferred means of inter-city transportation, though an option available only to the more affluent members of society. This is reinforced by the poor state of the roads and other issues surrounding road travel safety, though there are also concerns about the safety of air travel with three major airline disasters between 2005-2006 (Daramola \& Jaja, 2011; Mintel, 2007) and recently in 2012 and 2013. Train travel is underdeveloped with many routes discontinued; however, recent government investment has revived a train route from Lagos to Kano, but the journey takes over 24 hours and operates only once weekly in each direction. The buses available for public transport are old adding to a preference for car or air travel.

The country is not a popular tourist destination due to a "poor international image" (Iyiola \& Akintunde, 2011, p. 28), inadequate modern infrastructure, underdeveloped tourist destinations and reports of violence (Charles, 2010). As for domestic tourism, citizens are poorly aware of tourism opportunities. Iyiola and Akintunde (2011, p. 29) add that, with positive change in the Nigerian government's interest in the tourism sector, it is presumed that "there are more exciting days" for tourism in the country. 
Nigeria is, therefore, not an African country with a strong tourism economy. However, it presents an interesting case in which to explore understandings of climate change, given its rich oil reserves that underpin the country's foreign exchange earnings. This has led to wealth generation opportunities and development potential with a growing number of Nigerians engaging in outbound international tourism (World Tourism Organisation 2012b). Nigeria is also one of the countries vulnerable to climate change (Parry et al., 2007). It lies in a midlatitude region that is expected to suffer from longer droughts that threaten the country's food security. The growth of tourism is threatened by climate change impacts on biodiversity and destruction of cultural heritage attractions (Scott et al., 2012). Economic growth and political stability is also at risk. Furthermore, climate change puts tourists at risk due to increase in vector-borne disease outbreaks such as malaria and diarrhea (Scott et al., 2012).

Nigeria therefore makes an interesting developing country to study. There is both scope to develop the internal tourism industry, under the right political conditions, and a growing outbound tourism market. At the same time it remains vulnerable to climate change and therefore presents a classic paradox of the desire to grow both internal tourism and the outbound market while this adds to the burden of climate change.

\section{Methodology}

Given the paucity of knowledge on this topic in a developing country context, an inductive approach was required that avoided drawing assumptions from the previous research conducted in developed countries. The study therefore employed in-depth interviews to explore individual participant's views of climate change and the tourism context. In order to explore the link between tourism and climate change, participants were purposefully chosen on the basis of two criteria: 1) expressed awareness of the term 'climate change'; and 2) some tourism travel experience. The participants were a mixture of male and female with ages ranging from 22 to 58. They can be considered relatively affluent in the Nigerian context. Some participants had travelled for business purposes but also used the opportunity to visit tourist attractions during business travel. Six were university graduates, of which five were schooled outside Nigeria, mainly in Europe. Two of the participants were undergraduate students and one retired (see Table 1 for participant details). A snowballing technique was used to find participants based on two initial contacts in Nigeria. This facilitated contact with participants who met the study criteria and could be interviewed in Lagos or Abuja to minimize travel costs. This limited the scope of the study to an urban population; however, the participants were not intended to reflect the wider Nigerian population but to reflect the affluent population engaging in tourism and travel.

The interviews began with questions regarding participant's tourism experiences before moving on to more sensitive questions on understanding of climate change and the link between climate change and tourism. The interviews were conducted face-to-face in Nigeria during October 2012. Data were transcribed and initially coded according to four areas of interest: views on climate change; the link between travel/tourism and climate change; willingness to change travel/tourism pattern; and barriers to change.

\section{Findings and discussion}

The participants selected for the interview were chosen based on their self-declared awareness of climate change. It transpired that one participant, Zoe, was unable to articulate 
any comprehension of the term, so the interview was terminated. The remaining 19 participants were all able to express some view on climate change although some gave vague and intuitive answers such as "climate change is, as the word suggests, a change in the climate". Lorraine indicated that the topic was currently circulating in Nigerian society: "well it is difficult not to know anything about climate change right now because so much attention is being paid to it". In this respect, several participants recollected hearing about climate change from reading a magazine or the television (Alfred, Tola and Obi). This general awareness of climate change is consistent with studies in developed countries where a rudimentary knowledge of the topic is widespread but detailed knowledge is rare (McKercher $\&$ Prideaux 2011). Analysis derived six themes from the data which are discussed below.

\section{Direct experience translated by a cultural model of climate change}

Most of the participant's related 'climate change' to what they have observed or experienced, such as a change in the weather pattern. This was especially evident in discussion of changes to the rain pattern in the capital city of Abuja and other parts of Nigeria, what one participant called "August break":

"this is the first time we are having rains in Abuja till October. Abuja rains stops most time end of August or early September, the rain patterns have changed.” (Obi)

"here in Nigeria we are used to what is known as the August break where towards the end of August the rains stop and then they start again in September and then end but in the past two years it's more like an October break. Rains stop in October, start again in November before they cease." (Josh)

A number of the participants referred back to what they had been taught in school science about the timing of seasonal change. They mentioned a new irregularity in the rainfall pattern where the rainy season is known to end at a certain month but due to climate change the rainy season is prolonged. The country has two main seasons, the wet season which is between April and October and the dry season between November and March (Mintel 2007).

Consistent with the research by Hares et al. (2010), where the participants related climate change to changes in weather pattern experienced in their life time, the answers given by most participants in this study were based on their past experience. Six participants made use of the phrase "used to" stating that the weather is not the way they have known it to be in the past. Participants also made reference to the recent flooding, increased heat, desert encroachment and erosion experienced in Nigeria; for instance, areas not known to be prone to flooding in the past were flooded. As per the weather, these observed physical changes were seen as an impact of climate change. This perceived direct experience of climate change is more marked than that found in previous research.

Kempton (1997) similarly found that participants attributed weather changes to climate change alongside other anthropogenic causes, suggesting this is a cultural model in which people are predisposed to blame weather changes on human activity. The participants' sense that they had personally observed changes in weather patterns during their lifetime is a powerful force with direct implications for tourism opportunities. Given there is some alignment of personal observation with climate scientists Kempton (1997) suggests this enables lay people to grasp climate change that might otherwise remain an abstract scientific concept. Climate is, however, long term whereas weather refers to the day-to-day conditions that people experience. As such weather cannot be directly attributed to climate change. Even scientists monitoring weather events are unable to attribute unusual weather patterns to 
climate change, however, the concepts are linked and there is widespread association of unusual weather events with climate change.

Similarly, some participants referred to 'global warming', "it's the global warming thing happening now I think" (Bidemi), while many participants mentioned the temperature being warmer and the ice caps melting in polar regions:

"the heat is becoming much more and from what I heard it is affecting the north pole ice which is increasing the sea level and affecting all the rivers in the world, flooding everywhere" (Anthony)

"I have heard that the ice is dissolving and it needs more space and it is expanding and reclaiming part of the land we are accustomed to using" (Tola)

Here Anthony and Tola draw on a combination of direct observation, with reference to "heat" and water "reclaiming part of the land" and social transmission of the idea of global warming when they reference the polar ice caps. Global warming is just part of climate change (Weber \& Stern, 2011), however, it is clear from these interviews and other studies (Lorenzoni \& Pidgeon, 2006) that this is the primary feature that lay people understand in both developed countries and Nigeria. Anable et al. (2006, p.16) argue that although different types of extreme weather conditions and temperature and rainfall variations "can be experienced as individuals, global warming cannot". This is illustrated in the Nigerian's direct experience of weather variations, but more circumspect description of global warming. For example, both Anthony and Tola state "I have heard" and link this to floods that have been experienced in the country. Akpan et al. (2012) suggest that some of the knowledge developing countries, such as Nigeria, have about climate change is from what they have listened to on "foreign media".

\section{Misconception of climate change}

The participants had several misconceptions about what causes climate change although there was evidence that some understood the role played by GHG emissions. A particular misconception linked climate change to the ozone layer. For example, Alfred stated:

"What I know about it is that the ozone layer is being depleted due to the carbon released into the atmosphere from the environmental pollution" (Alfred)

Patience gave a similar answer, which suggests that man's activities had led to the depletion of the ozone layer:

"what I know about climate change is that man's activity has affected the ozone layer and that has resulted in warmer atmospheric environment" (Patience)

Lorenzoni and Pidgeon (2006) found that studies conducted in developed countries during the 1990s showed that people confused climate change with ozone layer depletion. This confusion was still apparent to some extent in McKercher and Prideaux's (2011) later study, conducted in 2008, where tourism students identified ozone depletion and other 'spurious' causes of climate change. Ozone layer depletion and climate change are unrelated; however, given their link to the atmosphere it is common for lay people to confuse them. In addition, Kempton (1997) and Read, Bostrom, Morgan, Fischhoff and Smuts (1994) suggest that both 
the ozone layer and climate change were given much publicity by the media in the 1990s and have been discussed together in popular articles. Lorraine commented that climate change was getting much media attention and, in the recent study by Akpan et al. (2012) in Nigeria, the majority of the participants heard about climate change from the internet or television.

Participants also confused climate change with other environmental problems. For example, Lorraine commented on a recent trip to Taiwan where she experienced an earthquake, she added that these areas are disaster prone areas and humans are worsening it by releasing more "toxic and carbon into the atmosphere". Participants also aligned poor waste disposal in general with climate change:

"the way human beings have started living, people dump things in the rivers, waste in the rivers and all that" (Diana)

Here Diana refers generically to dumping of materials which, though a waste management and pollution issue, may not directly cause climate change depending on the type of waste. Most participants mentioned pollution and waste disposal as a cause of climate change. For example, Tola suggested that poor waste disposal practices in Nigeria had led to recent flooding because waste was clogging the drainage system. This is unrelated to climate change.

Weber and Stern (2011) argued that though there have been advances in explaining the science of climate change to non-scientists, the confusion of climate change with weather and confusion of the causes of climate change with a variety of forms of pollution is as dominant as it was in the 1990s. Some forms of pollution such as GHGs emissions can cause climate change but other forms, such as the release of chemicals into rivers, while significant environmental problems, are less likely to directly cause climate change. Participants were unable to make clear distinctions.

\section{Oil, technology and industrialization}

Participants related climate change to technology and industrialization, for example:

"It's human activities but it is expected with development and all the technological changes and everything...it's something that would have come either way... because as man looks to progress and look for things to make life easy...make machines and all the machines you have to fuel them and the only fuel they have is what is causing all the damage" (Gambo)

Here Gambo begins to get at the root cause of climate change in her reference to the fuel used. Josh extends this by comparing the emissions standards in Nigeria to elsewhere:

"I know that abroad cars are tested to show that the emissions levels of the car are not above a certain level that can pollute the environment, once the car is tested and it exceeds it, the car is grounded and in Nigeria nobody cares"(Josh)

Josh rightly explains that emissions from cars and generators, which are a very common means of supplying electricity in Nigeria due to inefficient power supply, are major contributors to climate change. In the study by Reynolds, Bostrom, Morgan, Fischhoff \& Smuts (2010, p.1526) more than a third of the respondents mentioned cars and industry which suggests "a general appreciation for these causes of climate change". 
Given Nigeria's economic dependence on oil it was surprising how little fossil fuel was mentioned as an issue. In reference to the earlier discussion of pollution, Lorraine stated that some companies, especially oil companies, get away with this due to their influence and the role they play in the growth of the country's economy:

"largely industrialization has contributed greatly and then the quest for growth without taking responsibility to clean up...most companies will take a shortcut if you let them and of course they are allowed to because they are the 'movers and shakers' of the society...no government wants to destroy its industrial output and all that because that's what runs the economy and so these people are allowed to get away with leakages, oil spills, toxic materials being released into the rivers all kind of things" (Lorraine)

Given Nigeria's economic dependence on oil, Lorraine suggests that the Government is unwilling to tackle these issues. Similar China has also faced the challenge of growing its economy and controlling environmental pollution (Zhang \& Wen, 2008). Perhaps what is unexpected, given that some participants understood the relationship between fossil fuel, GHG emissions and climate change, is the relative absence of discussion about Nigeria's oil reserves. It is not clear whether this issue was suppressed by participants or whether oil reserves are such a feature of Nigeria that participants fail to appreciate its significance relative to other countries.

\section{Link between travel and climate change}

Despite a basic knowledge of climate change, the majority of participants could not initially articulate any link between travel and climate change; either they did not understand the link at all or they did not think it had any connection to their travel or holidays. This is similar to the UK findings of Hares et al. (2010) which indicated that climate change was not associated with holidays or the link was somehow suppressed. Becken (2004) also found that tourists rarely make the connection between causes and effects. Some participants suggested that climate change affects travel and a few recognized that the emissions of cars and airplanes cause climate change. Given that some participants had no answer to give, the researcher explained further by asking what role they think they play in climate change with regards to their travel and tourism.

Participants were initially most inclined to view climate change as an aspect that would impact on holidays relative to changing weather patterns, a similar finding to Becken (2007) and Hares et al. (2010). In research by Hares et al. (2010), weather was at the top of the list for participants when making decisions for travel/holiday and Gössling, Scott, Hall, Ceron and Dubois (2012) note the significance of climatic conditions in tourism decisions. This was also evident in the Nigerian sample, for example:

"If I'm going to make a trip I generally look for warm places, I never look for cold. Apart of the excitement of being in another town, generally the weather is what I consider. I think that's the link for me." Bidemi

\footnotetext{
"well, many times when you are travelling you...like for me I always go check the weather first to see where I'm going to because you do not want something that's too extreme for you especially when you are coming from Nigeria, going to somewhere like Europe" (Eghiro)
} 
Both Bidemi and Eghiro's comments reflect the relatively warm and stable climate in Nigeria and their desire to avoid the cold. Participants also reflected on how the weather affected transport infrastructure. Josh stated that climate change can limit transport choices and he referred back to the recent floods in Nigeria where major roads were affected:

"If the climate is not conducive you hardly can fly, the floods we had of recent affected transportation. Lokoja, which is the major link between the north and the east the south and the west, was cut off completely, vehicles could not pass till the government had to create access for the vehicles, to a large extent whatever happens to the climate affects transportation." (Josh)

Anthony made a similar statement that "it restricts your movements and where you are supposed to go". Clearly the participants did not see the reverse link as the GHGs released when travelling or taking a holiday. Hares et.al (2010, p. 469) argued that this questions whether people conceptually link the impact of tourism to climate change. However, when questioned about the role they play in climate change, five participants did recognize that tourism travel generates GHG emissions, and, of these, four made a link to air travel. With some prompting, most participants referred back to emissions from transportation and generators by admitting to owning a generator or a car and "driving out every day". This shows awareness of fossil fuel consumption and emissions.

Of those able to recognize that tourism travel generates GHG emissions, Patience described her love for travelling, how she prefers to go by air, and made a comment on airplanes emitting "their own type of gases which is harmful to the atmosphere". So when questioned about the link between holidays and climate change she confidently said it was "the emission of the gas" which she explained is harmful to the atmosphere. Lorraine was also able to describe emissions from transportation and also emissions released during the production of fuel, which is a reference to Nigeria's oil industry:

"the aircrafts and the things we need to use in travelling from one point to the other use fuel so you look at the point where the fuel is being produced gases are released into the air in the course of producing the air and you are looking at the point of consumption...the aircraft itself being able to move releases the waste into the atmosphere and that's even closer to the ozone layer so there is a direct link....yes more and more people are travelling by air, it plays a greater impact." (Lorraine)

Here Lorraine additionally identifies the height of aircraft as a problem, though conceptually she links this incorrectly to the ozone layer rather than radiative forcing.

\section{The desire to travel}

From the previous sections, it is evident that some participants recognized some of the causes of climate change and how human activities such as transportation are contributors to climate change. In cases where the participants did not explicitly make a link between their tourism travel and climate change, the researcher referred them back to statements they had made about emissions from cars or airplanes. The researcher was then able to question the participants on their willingness to change their travel patterns in order to reduce its effect on 
climate change. Responses indicate a strong desire to maintain current travel practice. Lagos, a city frequently visited by most of the participants, was used as an example. Bidemi mentioned that she would be travelling to Lagos from Abuja by air for a wedding and she was asked if she would be willing to use an alternative mode of transportation.

“hmm in Nigeria No... I won't change my mind" (Bidemi)

All participants gave a similar response to Bidemi when questioned about their willingness to change their travel pattern. Patience, who had expressed her love for travelling within and outside Nigeria, promised that she would not reduce her rate of travelling, though she was one of the few able to point out the link between tourism travel and climate change.

"if you are asking me to reduce my travel, I will say no! I promise you that" (Patience)

This is similar to the research by Hares et al (2010, p. 472) which showed that with regards to holiday and climate change, awareness did not result in a 'pro-environmental' attitude linked to tourism travel or subsequent behaviour change intention. All participants displayed a "reluctance to change lifestyle" (Lorenzoni, Nicholson-Coles \& Whitmarsh, 2007, p. 449). The participants were not ready to give up certain travel lifestyles though it would mitigate the impacts of climate change on the environment. In another example, though Thomas admitted that his travelling by air and by road regularly contributes to climate change, he pointed out that the role he plays in climate change, as an individual, may be minimal. $\mathrm{He}$ stated that helping to reduce the impact of climate change on the environment had nothing to do with his travel:

"it is my convenience that I will think of...I can travel by air when I have the means and when I don't have the means I will travel by road, I don't think I will change my attitude ...that means I don't give a damn about what is happening around, about climate or anything, as long as I will achieve my aim, so I will not change." (Thomas)

In this case Thomas is prepared to openly admit that he does not care about his impact on climate change. Interpreted through the lens of social practice theory, Thomas anticipates a degree of social acceptance of his view. He feels no stigma attached to claiming not to care. Conversely, as Nigeria is at a stage of development where travel opportunities are opening up to more people in society, travel is seen as desirable.

\section{Fly over the problem}

When asked about their willingness to change their travel/tourism behavior in order to reduce its effect on climate change, all the participants gave a variety of reasons explaining why they would not reduce their rate of travel or use an alternative means of transportation. This was especially contextual to the physical transport structures available in Nigeria and its sociopolitical conditions. These are structural barriers.

Some participants stressed the "need" to travel, especially those that travel not only for tourism or holidays but also for business purposes. To these participants their finances and "getting things done" were a priority compared to pro-environmental behavior. Lorenzoni et al. (2007, p. 452) suggests that this may be due to the participant's view of climate change as "distant in space and time". 
"there are things you need to do and you need to get them done. If the trips were all leisure you decide to travel once a year instead of twice." (Lorraine)

"NO! The things I need to do officially put money in my pocket and the other ones are the only times I get to relax" (Obi)

Lorraine, who owns a private company, travels frequently to different countries to make purchases and therefore believes that she can only reduce her travel if all her trips were leisure. Obi who travels within the country agrees and suggests that the times he travels or takes holidays are the only times he gets to relax and he would not want to let go of that opportunity. Eghiro also mentioned the 'need' to travel suggesting the only reason he would decide not to travel is when there are no activities to be done. Similarly, Beatrice who travels within and outside Nigeria for business/leisure stated that she would be willing to travel less if she has enough 'capital base'.

Patience, on the other hand, talked about the 'importance of holidays' (Hares et al., 2010): "see where I am getting to now, I am getting to retirement... I am looking forward to travelling" (Patience)

Patience views retirement as an opportunity to travel. Stoll-Kleemann et al. (2001, p.112) termed this as "the comfort interpretation", a form of denial where a person is not willing to give up certain lifestyles and habits that are associated with a sense of identity (Hibbert, Dickinson, Gössling \& Curtin, 2013). This illustrates the role played by individual agency.

Other participants described barriers that were unique to Nigeria that led to air travel:

"the best thing to do is to fly over the problem and reach your destination in one piece" (Alfred)

For travel and holidays within Nigeria, some participants would like to use an alternative mode of transportation to air travel if it was made available and can meet their needs such as comfort, travel time and security. Given the poor state of the road infrastructure in Nigeria and dangers from criminal activity, overland travel was not considered viable. Randles and Mander (2009, p. 95) describe the propensity for people to be "locked-in" to practices leading to "resistance to change". This also echoes Lorenzoni et al. (2007, p. 453) who showed that participants were willing to change but were constrained by the "lack of enabling infrastructures and mechanism". Here both physical and societal structures reinforce air travel. This was further emphasized as participants involved in international travel compared the modes of transportation available in Nigeria to those in developed countries. For example:

"like what we have outside Nigeria, we have this fast train, I will really love to use them if they are available... I will even prefer them to flying because you see more, you learn more... well the Nigerian roads are also nothing to write home about...if our rail system was working we will have less pressure on the road so what we need to do in Nigeria should be that we work on our rails to be like what we see outside the country so the pressure on the road will reduce." (Patience)

The majority of the participants complained about the uncomfortable nature of the public transport system in Nigeria and mentioned the need for improvement. This is also a common finding in developed countries (Dickinson et al., 2010; Hares et al., 2010; Lorenzoni et al., 2007) despite public transport having a much higher level of comfort. On the whole car travel, 
though not much more sustainable than air travel, was also disregarded if air travel to the destination was available and participants stressed the risks of car driving or using public transportation, including the security situation in the country, poor roads prone to accidents and travel time. One of the participants (Anita) admitted that if there were air travel available from Abuja to Kaduna, two cities in Nigeria that are two hours apart by car, she would travel by air.

"unfortunately where you find yourself is Nigeria....maybe they are trying to help by introducing the train system, so the only way it will work that I will try to help and not travel by air to Lagos is to use a train but a car?.... of course you know it is unsafe in Nigeria if you travel by car, they will kill you...so the only option will be to travel less which I have tried to do" (Anita)

"well in Nigeria, I look at the time, convenience, the stress of our roads... our roads are not wonderful, there are different risks on Nigerian roads depending on what part of the country you are going to. Sometimes you are travelling the roads are blocked, people are fighting, armed robbers on the road .... at the end of the day, you just want to take your flight and forget about the roads" (Eghiro)

Similar to the point made by Alfred, the participants would choose to travel by air if available in order to "fly over the problem" and reach their destination. This can be seen as a "structural or psychological barrier" (Hares et al. 2010, p. 471). Another point made by the participants with respect to this barrier is the "reliance on technology" (Lorenzoni et al. 2007). A "technology will save us" mind set was prevalent, with several pointing out that they have heard about environmental friendly modes of transportation and the only thing that needs to be done is to "pursue aggressively the opportunity to create such" (Lorraine) modes of transportation.

"I don't think I want to travel less or fly less, rather, I want the scientist, the same way they discovered means of transportation that affects the environment, they should also discover some things that fly very fast without affecting the environment, they should have some green planes" (Eghiro)

"there has not been an adequate alternative so it is left for the people in that field, the professionals to provide an alternative means or redesign the aircrafts in a way that the aircrafts will not have harm to the atmosphere." (Alfred)

This can be described as a reliance on technology to solve the problem (Stoll-Kleemann et al., 2001; Lorenzoni et al., 2007). Participants also assume others will do something about the problem:

"we are not the ones to suffer, airline companies are the ones to start making ecofriendly planes" (Anita)

"sometimes you wish there's something you can do but what can you do when you are not one of the policy makers or you find yourself in a circle where you can do something about it" (Lorraine)

Here participants attribute responsibility to others (Hares et al., 2010). The statement by Lorraine also points to what Stoll-Kleemann et al. (2001, p.112) referred to as "denial of 
responsibility and powerlessness". Four of the participants argued that changing their travel pattern in order to reduce the effects of climate change would not make a difference. This 'sense of powerlessness' is evident in the following:

"if I say I want to reduce the rate of climate change by using an alternative means of transportation, how much will my little good be? Because there are certain people that will not be willing to take other means of transportation" (Alfred)

"it's more or less like a passive knowledge because other people are still flying, so if I decide to stop flying who is it going to affect? It's me it will affect at the end of the day" (Diana)

Both Alfred and Diana argue that if they changed their behaviour other people may not be willing to make that change and they justified their inactivity by "the lack of action by others" (Hares et al., 2010, p. 471). One of the participants, Natasha, showed a sense of 'fatalism' (Lorenzoni et al., 2007) about climate change:

"I don't think changing my mode of transportation would make a difference...I think the weather change is more natural, I feel it is a natural process that would definitely occur so changing your mode of transportation left to me would not make much difference" (Natasha)

Here Natasha points to the belief that climate change is natural and therefore any change in behavior would not make a difference.

The analysis suggests unsustainable travel practice, particular air travel, is deeply embedded in affluent Nigerian society. Existing practice is reinforced by physical structures, such as poor road infrastructure and the scale of the country such that key destinations are geographically dispersed. There are also social structures that reinforce practice, especially safety concerns, that represent very real physical concerns. It is also apparent that travel is highly desired for both economic and identity purposes. As a result Nigerian tourism is currently "locked-in" (Randles \& Mander, 2009) to air travel as a preferred mode of transport. There was some evidence of individuals feeling powerless to deal with the problem and a sense that 'others' should be doing something about it.

\section{Conclusion}

Given that little or no attention has been paid to understanding people's views of climate change and tourism in developing countries, this study has analyzed a Nigerian perspective. The findings indicate some awareness of climate change among the Nigerian public and, similar to other studies (Hares et al., 2010; Kempton, 1997; Miller et al., 2010), participants gave relatively simplistic accounts of climate change. There was some conceptual confusion related to ozone layer depletion and a variety of forms of pollution that contribute little to climate change. Although the Nigerians sampled identified cars and airplanes as contributors to climate change, most participants did not directly make a link between their travel/tourism and climate change. On establishing this link, most participants expressed an unwillingness to change their travel behavior to reduce their contribution to climate change. The findings are consistent with the previous studies conducted in developed countries and are significant given that Nigeria is located in a region susceptible to the impacts of climate change, where it might be anticipated that people would express more concern. 
It was evident that a variety of structural barriers related to poor transport infrastructure embed air travel practice in Nigeria. While the Nigerians in this study highlighted similar reasons for their unwillingness to change behavior to developed country studies, it was clear that structural barriers were a much stronger barrier, especially with respect to avoiding air travel. Participants agreed that there were no alternatives to flying which they considered safer, more comfortable and faster. Nigerian road infrastructure was considered to be poor, an issue likely to be prevalent in other developing countries, and road travel was associated with personal security risks. Nigerians engaging in tourism therefore dismiss the use of public transport or car travel.

Other barriers included the need to travel, where some participants suggested that it is the only time they get to relax and it is needed to maintain their finances and businesses. They were not willing to give up their lifestyle in favor of reducing their contribution to climate change. Stoll-Kleemann et al. (2001) refer to this as the comfort interpretation, a form of denial. Others believed that changing their behavior as an individual would not make a difference and that climate change is something that would happen regardless of any change made.

Given the exploratory and qualitative nature of this study it has not ascertained what proportion of Nigerians know about climate change or made any attempt at quantifying knowledge levels. The sample was selected on the basis of those who expressed some awareness of climate change in order to explore the links to tourism. It does not represent Nigerians as a whole but reflects relatively affluent Nigerians currently engaged in tourism.

Overall the evidence here suggests that, as with developed countries, there is little chance of stopping unsustainable tourism travel in Nigeria, even though this may have direct impacts through climate change close to home. It would trite to suggest Nigeria builds better roads, improves public transport and develops better awareness programs, since such strategies appear to have done little to address the issues elsewhere. Instead the findings highlight the immense obstacles to more sustainable tourism development in some regions of the world. Though tourism remains highly desirable as a development option, this may not be the best way forward for developing countries like Nigeria given that internal infrastructure is poor and this tends to lead to air travel becoming rapidly embedded in habitual behavior. It is therefore vital to understand that underlying structural issues and relatively poor adaptive capacity present significant barriers to a sustainable tourism pathway. Paradoxically, though based on different regions, and for different reasons, the Freiburg Workshop's conclusion (Higham et al, 2013, 962) that "the efficacy of individual consumers bearing the costs (social, economic) and responsibilities (psychological, behavioral) ...is clearly open to question...changes to the systems of provision are clearly required" is as apt in Nigeria as in developed countries. But how that could be achieved in Nigeria is a discussion for future researchers.

\section{Notes on contributors}

Hanny Dickson Dillimono is a postgraduate student at the School of Tourism, Bournemouth University, UK. Her research interests focus on tourism and climate change in developing countries. Janet Dickinson is a professor at the School of Tourism, Bournemouth University, UK. Her research interests focus on sustainable travel practice and include studies on slow travel, social representations, mobile social networking and time. 


\section{References}

Akpan, C., Anorue, L. \& Ukonu, M. (2012). An Analysis of the Influence of the Nigerian Mass Media on Public Understanding of Climate Change. Journal of Alternative Perspectives In The Social Sciences. 4(4), 688-710.

Anable, J., Lane, B. \& Kelay, T. (2006). An evidence based review of public attitudes to climate change and transport behaviour. London: Department for Transport, the stationary office. Retrieved October 11, 2013, from: http://www.fcrn.org.uk/sites/default/files/Evidence_of_public_attitudes_and_behaviour.pd $\underline{\mathrm{f}}$

Becken, S. (2004). How tourists and tourism experts perceive climate change and carbon offsetting schemes. Journal of Sustainable Tourism, 12(4), 332-345.

Becken, S. (2007). Tourists' perception of international air travel's impact on the global climate and the potential climate change policies. Journal of Sustainable Tourism, 15(4), 351-368.

Charles, U.A. (2010). Managing Tourism in Nigeria: the Security Option. Management Science and Engineering, 4(1), 14-25.

Cohen, S.A., Higham J.E.S. \& Cavaliere, C.T. (2011). Binge Flying Behavioural Addiction and Climate Change. Annals of Tourism Research, 38(3),1070-1089.

Cohen, S.A. \& Higham, J.E.S. (2011). Eyes wide shut? UK consumer perceptions on aviation climate impacts and travel decisions to New Zealand. Current Issues in Tourism, 14(4), 323-335.

Daramola, A. \& Jaja, C. (2011). Liberalization and changing spatial configurations in Nigeria's domestic air transport network. Journal of Transport Geography, 19(6), 1198 1209.

Dickinson, J.E., Robbins, D., Lumsdon, L. (2010). Holiday travel discourses and climate change. Journal of Transport Geography, 18, 482-489.

Dickinson, J.E., Robbins, D., Filimonau, V., Hares, A., Mika, M. (2013). Awareness of Tourism Impacts on Climate Change and the Implications for Travel Practice: A Polish Perspective. Journal of Travel Research, 52 (4), 506 - 519.

Esu, B. (2012). Linking Human Capital Management with Tourism Development and Management for Economic Survival: The Nigeria Experience. International Journal of Business \& Social Science, 3(11), 276-287.

Gössling, S., Scott, D., Hall, C., Ceron, J., Dubois, G., 2012. Consumer behaviour and demand response of tourists to climate change. Annals of Tourism Research, 39(1), 36-58.

Hall, C. \& Higham, J. (2005). Tourism, Recreation and Climate Change. Clevedon, Channel View.

Hares, A., Dickinson, J.E. \& Wilkes, K. (2010). Climate change and the air travel decisions of UK tourists. Journal of Transport Geography, 18(3), 466 - 473.

Hibbert, J.F., Dickinson, J.E., Gössling, S., Curtin, S. (2013). Identity and tourism mobility: an exploration of the attitude-behaviour gap. Journal of Sustainable Tourism, 21(7), 9991016.

Higham, J.E.S. \& Cohen, S.A. (2011). Canary in the coalmine: Norwegian attitudes towards climate change and the extreme long-haul air travel to Aotearoa/New Zealand. Tourism Management, 32(1), 98-105.

Higham, J.E.S., Cohen, S.A., Peeters, P. \& Gössling, S. (2013) Psychological and behavioural approaches to understanding and governing sustainable mobility Journal of Sustainable Tourism, 21(7,) 949-967.

Ikeme, J. (2003). Climate change adaptational deficiencies in developing countries: the case of Sub-Saharan Africa. Mitigation and Adaptation Strategies for Global Change, 8, 2952 . 
Iyiola, O. \& Akintunde, O. (2011). Perceptions as Influencer of Consumer Choice Behavior: The Case of Tourism in Nigeria. Journal of Marketing Development \& Competitiveness, 5(7), 27-36.

Kempton, W. (1997). How the public views climate change. Environment, 39(9), 12.

Lorenzoni, I. \& Pidgeon, N.F. (2006). Public views on climate change: European and USA perspectives. Climate Change, 77(1-2), 73-95.

Lorenzoni,I., Nicholson-Cole,S., Whitmarsh,.L. (2007). Barriers perceived to engaging with climate change among the UK public and their policy implications. Global Environmental Change, 17(3-4), 445-459.

Marshall, N., Marshall, P., Abdulla, A., Rouphael, T.\& Ali, A.(2011). Preparing for climate change: recognising its early impacts through the perceptions of dive tourists and dive operators in the Egyptian Red Sea. Current Issues in Tourism. 14(6), 507-518 .

McKercher, B. \& Prideaux, B. (2011). Are tourism impacts low on personal environmental agendas? Journal of Sustainable Tourism, 19(3), 325-345.

McKercher, B., Prideaux, B., Cheung, C. \& Law, R. (2010). Achieving voluntary reductions in the carbon footprint of tourism and climate change. Journal of Sustainable Tourism, 18(3), 297-317.

McMichael, C., Barnett .J. \& McMichael, J.A. (2012). An Ill Wind? Climate Change, Migration and Health. Environmental Health Perspectives, 120(5), 646-54.

Miller, G., Rathouse, K., Scarles, C., Holmes, K., Tribe, J. (2010). Public understanding of sustainable tourism. Annals of Tourism Research, 37(3), 627-645.

Mintel (2007). Travel and Tourism - Nigeria - May 2007. London: Mintel international group.

Nath, K.P. \& Behera, B. (2011). A critical review of impact of and adaptation to climate change in developed and developing economies. Environment, Development and Sustainability, 13(1),141-162.

Nigerian Tourism Development Corporation (2012). Tourists attractions. Retrieved

December 10, 2012: http://tourism.gov.ng/

Parry, M.L., Canziani, O.F., Palutikof, J.P., van der Linden P.J. \& Hanson, C.E. (2007). Climate Change 2007: Impacts, Adaptation and Vulnerability. Cambridge, Cambridge University Press. Retrieved September 30, 2013, from: http://www.ipcc.ch/publications_and_data/publications_and_data_reports.shtml.

Peeters, P. (2009). Pro-Poor Tourism, Climate Change and Sustainable Development. Tourism Recreation Research, 34(2), 203-205.

Pickering, C., Castley, J. \& Burtt, M. (2010). Skiing Less Often in a Warmer World: Attitudes of Tourists to Climate Change in an Australian Ski Resort. Geographical Research, 48(2),137-147.

Randles, S. \& Mander, S. (2009). Aviation, consumption and the climate change debate: 'Are you going to tell me off for flying?'. Technology Analysis and Strategic Management, 21(1), 93-113.

Read, D., Bostrom, A., Morgan, G.M., Fischhoff, B. \& Smuts,T. (1994). What do people know about global climate change? Survey studies of educated laypeople. Risk analysis, 14(6), 971-982.

Reckwitz, A. (2002). Toward a Theory of Social Practices: A Development in Culturalist Theorizing. European Journal of Social Theory, 5(2), 243-263.

Reynolds,W.T., Bostrom, A.,Read, D. \& Morgan, G.M. (2010). Now What Do People Know About Global Climate Change? Risk Analysis, 30(10), 1520-1538.

Schott, C. (2010). Tourism and the implications of climate change: issues and actions. Bingley, Emerald. 
Scott, D.C., Hall, M. \& Gössling, S. (2012). Tourism and climate change: impacts, adaptation and mitigation. London, Routledge

Scott, D., Peeters, P. \& Gössling, S. (2010). Can tourism deliver its "aspirational" greenhouse gas emission reduction targets? Journal of Sustainable Tourism, 18(3), 393-408.

Simpson, M.C., Gössling, S., Scott, D., Hall.C.M. \& Gladin, E. (2008). Climate Change Adaptation and Mitigation in the Tourism Sector: Frameworks, Tools and Practices. Retrieved October 3, 2013, from: http://sdt.unwto.org/sites/all/files/docpdf/ccoxford.pdf

Spaargaren, G., van Vliet, B.J.M. (2000). Lifestyles, consumption and the environment: the ecological modernisation of domestic consumption. Environmental Politics 9(1), 50-77.

Stoll-Kleemann, S., O'Riordan,T., Jaeger,C.C. ( 2001). The psychology of denial concerning climate mitigation measures: evidence from Swiss focus groups. Global Environmental Change, 11, 107-117.

Tol, S.J.R. (2004). The marginal damage costs of carbon dioxide emissions: an assessment of the uncertainties. Energy Policy, 33(16), 2064-2074.

Weber,U.E. \& Stern,C.P. (2011). Public understanding of climate change in the United States. American Psychologist, 66(4), 315-328.

World Tourism Organization (2011). Tourism Towards 2030 / Global Overview. Madrid, UNWTO.

World Tourism Organization (2012a). Yearbook of Tourism Statistics dataset. Madrid, UNWTO.

World Tourism Organization (2012b). Data on Outbound Tourism (calculated on basis of arrivals in destination countries) dataset. Madrid, UNWTO.

Zhang, K. \& Wen, Z. (2008). Review and challenges of policies of environmental protection and sustainable development in China. Journal of Environmental Management, 88(4), 1249-1261. 
Table 1. Participant profile

\begin{tabular}{|c|c|c|c|c|}
\hline Pseudonym & Gender & Age & Tourism experience & $\begin{array}{l}\text { Number of flights in the } 2 \\
\text { years prior to interview }\end{array}$ \\
\hline Obi & Male & 40 & Business and local travel & ( \\
\hline Anthony & Male & 26 & Local travel & 1 \\
\hline Josh & Male & 39 & International/local travel & $5-10$ \\
\hline Beatrice & Female & 57 & $\begin{array}{l}\text { International/local and } \\
\text { business travel }\end{array}$ & Over 10 \\
\hline Bedemi & Female & 30 & $\begin{array}{l}\text { International/local and } \\
\text { business travel }\end{array}$ & Over 10 \\
\hline Patience & Female & 55 & $\begin{array}{l}\text { International/local and } \\
\text { business travel }\end{array}$ & $5-10$ \\
\hline Lorraine & Female & 38 & $\begin{array}{l}\text { International/local and } \\
\text { business travel }\end{array}$ & Over 10 \\
\hline Eghiro & Male & 41 & $\begin{array}{l}\text { International/local and } \\
\text { business travel }\end{array}$ & Over 10 \\
\hline Alfred & Male & 31 & $\begin{array}{l}\text { International/local and } \\
\text { business travel }\end{array}$ & $5-10$ \\
\hline Anita & Female & 24 & $\begin{array}{l}\text { International/local travel, } \\
\text { schooled in Europe }\end{array}$ & Over10 \\
\hline Martha & Female & 25 & $\begin{array}{l}\text { International/local travel, } \\
\text { schooled in Europe }\end{array}$ & Over 10 \\
\hline Thomas & Male & 58 & $\begin{array}{l}\text { International/mostly local } \\
\text { travel }\end{array}$ & $\begin{array}{r}\text { Uncertain but had used air } \\
\text { travel }\end{array}$ \\
\hline Tola & Female & 48 & $\begin{array}{l}\text { International/local and } \\
\text { business travel }\end{array}$ & Over 10 \\
\hline Bola & Male & 50 & International/local travel & Over 10 \\
\hline Gambo & Female & 22 & $\begin{array}{l}\text { International/local travel } \\
\text { schooled in UK }\end{array}$ & Over 10 \\
\hline Magdalene & Female & 24 & $\begin{array}{l}\text { International travel schooled } \\
\text { in UK }\end{array}$ & $5-10$ \\
\hline Diana & Female & 23 & International and local travel & Over 10 \\
\hline Natasha & Female & 25 & $\begin{array}{l}\text { International and local travel } \\
\text { schooled in Russia }\end{array}$ & 2 \\
\hline Steven & Male & 31 & Local travel & 0 \\
\hline Zoe & Female & 26 & Local travel & 0 \\
\hline
\end{tabular}

